\title{
SEGREGATION AND PREFERENCES FOR REDISTRIBUTION
}

\author{
Dilara Tosu
}

Montserrat Vilalta-Bufí 
Title: Segregation and preferences for redistribution

Abstract: We study the relationship between segregation and preferences for redistribution in Europe. We measure segregation as the incidence of assortative mating in terms of education and occupation. Assortative mating is measured at the regional level for 10 European countries using the IPUMS data. We combine these data with eight waves of the European Social Survey (2002-2016). We find that increased socioeconomic segregation in most forms of assortative mating leads affluent individuals to support less redistribution. Results suggest that affluent individuals are less socially attached when there are high levels of segregation.

JEL Codes: D31, D63, Z13

Keywords: Segregation, assortative mating, preferences for redistribution, European regions

\section{Authors:}

Dilara Tosu

Universitat de Girona

Email: dilaratosu@gmail.com
Montserrat Vilalta-Bufí

Universitat de Barcelona, BEAT, CREB

Email: mmontsevilalta@ub.edu

Date: March 2021

Acknowledgements: We are grateful to Elena del Rey, Javier Olivera and Angel SolanoGarcía for helpful comments and suggestions. Montserrat Vilalta-Bufí gratefully acknowledges financial support from the Spanish government through the grant RTI2018093543-B-I00, MCIU/AEI/FEDER, UE. 


\section{Introduction}

Over the last decades, income inequality has increased significantly in many industrialized countries while redistribution has remained stable or decreased in most countries (OECD, 2016). This contradicts the seminal Meltzer and Richard (1981) model, which predicts that an increase in income inequality is positively related to a higher demand for income redistribution in the country. In their model, individuals' only concern is to maximize their after-tax income where the redistribution rate is determined by a majority voting rule. The empirical literature finds mixed results about the relationship between pretax income inequality and redistribution. As Alesina and Giuliano (2011) state, the lack of empirical consensus suggests that there are other relevant determinants of preferences for redistribution apart from individual's income. Several papers have contributed to this literature by extending the analysis along multiple dimensions (see the next section for a literature review). In this paper, we explore the role of segregation in explaining preferences for redistribution.

At least two theories predict a negative effect of segregation on the preferences for redistribution. On the one hand, Bjorvatn and Cappelen (2003) show that residential income segregation might arise as a consequence of high income inequality. Moreover, they argue that segregation may reduce the social attachment of the rich with other groups in the society, which reduces their willingness to share their prosperity with the poor. In this case, segregation reduces the preference for redistribution of the affluent. On the other hand, Windsteiger (2017) shows in a model that in the presence of segregation, individuals may perceive a lower level of inequality than the actual level. This misperception of inequality leads people to support less redistributive policies. The latter mechanism applies to all individuals in the society.

We empirically estimate how preferences for redistribution are affected by segregation in the society. If segregation only affects negatively the preferences of the affluent, our results will support the social attachment mech- 
anism of Bjorvatn and Cappelen (2003), while a general negative effect of segregation for all individuals will point towards the mechanism of less perceived inequality proposed by Windsteiger (2017).

We use assortative mating as a measurement for social segregation in a region (see Schwartz, 2013, for a review of the literature on assortative mating). Assortative mating might be the result of residential segregation, which reduces the likelihood that individuals from different backgrounds meet, or due to differences in lifestyles and preferences of different social groups. Both cases imply little interaction between different groups in the society, which leads to real social segregation. Bruch and Mare (2009) explain how assortative mating in race, educational attainment, social class background, and religion act as segregation processes in the society. We follow Greenwood et al. (2014) to compute assortative mating in each region. We exploit the data for socio-economic status of spouses from the IPUMS (Integrated Public Use Microdata Series, Minnesota Population Center (2019)) to calculate first the fraction of couples with the same education level for each region as the actual matching; then we compute the fraction of both partners that would have the same education level by random matching using contingency tables. The ratio of the actual to random matches yields the values for education assortative mating. We compute analogously an alternative measure of assortative mating based on individual's occupation.

We investigate the relationship between differences in the incidence of assortative mating and individuals' attitudes to redistribution on a sub-national scale. We use the individual attitudinal data from the biannual 2002-2016 waves of the European Social Survey (ESS) (2018) for 111 regions in 10 different European countries. Many papers study different aspects of educational assortative mating (Blossfeld, 2009; Skopek et al., 2010; Smits et al., 1998; Stevens, 1991) as well as assortative mating by occupation (Hout, 1982). As far as we know we are the first to study the effect of assortative mating on preferences for redistribution.

The rest of the paper is organized as follows. Section 2 provides a lit- 
erature review on inequality and preferences for redistribution. Section 3 explains the data and methodology used. Results are presented in Section 4. We conclude in Section 5.

\section{Literature Review}

A large body of literature in political economics discusses the relationship between income inequality and redistributive preferences. In the seminal Meltzer and Richard (1981) model, there is a positive relationship between income inequality and the demand for income redistribution in a given country. Several authors confirm this positive effect of inequality on preferences for redistribution (see, e.g., Borge and Rattsø, 2004; Finseraas, 2009; Karabarbounis, 2011; Milanovic, 2000; Olivera, 2015). Olivera (2015) finds that variations in income inequality are positively related to variations in preferences for redistribution over time. Nevertheless, Georgiadis and Manning (2012) identify a negative relationship. They find that the demand for redistribution declines in the UK while income inequality increases. Moreover, in several studies no significant association was found (e.g., Gouveia and Masia, 1998; Kenworthy and McCall, 2007; Scervini, 2012). Alesina et al. (2004) also find that income distribution is not a significant determinant of redistribution.

Several studies provide alternative explanations about the relationship between inequality and preferences for redistribution. The prospect of upward mobility (POUM) hypothesis, for instance, states that when individuals expect to experience upward mobility in the society, they prefer less redistribution even if there is high inequality (Benabou and Ok, 2001; Alesina et al., 2018). Corneo and Grüner (2000) add two alternative mechanisms to the Meltzer and Richard (1981) model. First, they pose that individuals have preferences for redistribution independent of their income level. Second, they argue that individuals care about the effect of redistribution on their close social circle. They find support for both mechanisms. Some other papers highlight the difference between actual inequality and perceived in- 
equality. People tend to underestimate income inequality or their position in the income distribution (Cruces et al., 2013; Karadja et al., 2017; Norton and Ariely, 2011; Norton et al., 2014).

A strand of the political economics literature studies the impact of individual characteristics on preferences for redistribution. Iversen and Soskice (2001) find that individuals who have made risky investments in skills are less mobile than general, portable workers. Therefore, they may face an unemployment period or even suffer from a future income loss. To protect themselves from these risks, they are more prone to support government spending. The authors also add that union members, female individuals, and the elderly have strong incentives to support government spending. In contrast, self-employed individuals, better-informed individuals, and individuals who support right-wing parties are more likely to oppose social protection. White people are more prone to be against redistribution than black people (see Alesina and La Ferrara, 2005). Individuals who live in rural areas, as well as married individuals tend to support more redistribution (Ravallion and Lokshin, 2000). Cusack et al. (2006) find that publicly employed workers compared to private-sector workers, students and retired individuals are also more likely to embrace redistribution. The possibility of becoming unemployed plays a significant role on the preferences for redistribution (see Fernández-Albertos and Manzano, 2016). Rehm (2011) calculates the unemployment risk within a categorized occupation and its relation with preferences for redistribution. If the occupational unemployment risk increases then workers with a high risk of unemployment are more likely to approve government spending. Rehm (2011) also finds that better-off individuals in terms of income and higher educated individuals are more likely to disapprove redistribution policies.

Individuals' beliefs in effort and luck also affect the preferences for government spending. Alesina and Angeletos (2005) find that if a society believes that effort is an important determinant of income then they tend to demand low levels of redistribution, whereas if luck, family connections, or corrup- 
tion are believed to be more important to determine income, then they tend to support redistributive policies. Fong (2001) shows that individuals tend to be in favor of redistribution if they believe that the main determinant of poverty is exogenous. The political ideology is also a significant determinant of preferences for redistribution (see Alesina and Giuliano, 2011). Alesina et al. (2018) find that left-wing individuals support redistributive taxation. Moreover, those who are pessimistic about intergenerational mobility support even more redistribution.

Another line of research shows that culture is an important determinant for redistribution preferences. Luttmer and Singhal (2011) show that the attitude towards redistribution of immigrants depends on the redistribution policy in their country of birth. Alesina and Fuchs-Schündeln (2007) find that individuals from former East Germany are more likely to have proredistribution attitudes than individuals from West Germans after reunification. Corneo and Grüner (2002) show that individuals from former socialist countries tend to demand stronger preferences for reducing economic inequality than those from Western nations.

\section{Data and Methodology}

\subsection{Data}

We study preferences for redistribution using data from eight waves of the European Social Survey (ESS) which were carried out biannually from 2002 to 2016. The survey includes questions about individuals' attitudes towards redistribution as well as individual characteristics. It is widely used in the welfare state literature. ${ }^{1}$ Individual's preference for redistribution is measured as the individual's support to this statement: "The government should take measures to reduce differences in income levels". The respondents' answers vary on a scale from 1 to 5: disagree strongly (1), disagree (2), neither

\footnotetext{
${ }^{1}$ see Olivera (2015), Senik et al. (2009), Luttmer and Singhal (2011).
} 
agree nor disagree (3), agree(4), agree strongly (5).

We pool the eight waves of the ESS data and combine them with our regional measures of assortative mating. Our cross-sectional data of individual attitudes covers individuals in 111 regions of 10 European countries: Austria (AT), Italy (IT), Poland (PL), Spain (ES), France (FR), Switzerland (CH), Portugal (PT), Ireland (IE), Slovenia (SI) and Greece (EL). Our sample includes only individuals between 18 and 65 years old. The final sample size is 68,341 observations without missing information. The number of observations per region is 615 on average, ranging between 35 to 3,297 observations.

We add regional controls at the NUTS 2 level from several databases. The regional unemployment rate (population aged 15-74 years) and the percentage of tertiary educational attainment level (population aged 25-64) for the year 2001 are retrieved from Eurostat (Eurostat (2019)); regional gini index before taxes is from OECD (OECD Data (2019a)): France, Switzerland, Ireland, Slovenia and Portugal for 2010; Austria, Greece, Italy, Poland, and Spain for the year 2013. ${ }^{2}$ Finally, regional GDP per capita for the year 2001 is also from OECD (OECD Data (2019b)).

Table 1 provides the summary statistics of the preferences for redistribution, individual characteristics, and regional and political ideology variables. The demand for redistribution is high on average (4 out of 5 points). Most of the sample is native and around $63 \%$ have a partner. The average individual is 42 years old and lives in a household with three members. $30 \%$ of the sample has tertiary education and around $60 \%$ of the population in the sample are employed. Moreover, almost $52 \%$ of the people live in a village or a small city and the rest lives in a big city or the suburbs of big cities. The majority of individuals agree that they live comfortably or at least they are coping with their current income. However, $22 \%$ of them believe that they have difficulties living with their current income. An average individual has

\footnotetext{
${ }^{2}$ Note that we could not find Gini data for Ireland, Portugal, Greece, and Poland at the NUTS 2 level,so we use the data for these countries at the NUTS 1 level.
} 
a centrist political attitude (5 out of 10 points).

We use the IPUMS data to compute the measure of assortative mating at the regional level (NUTS 2 level). We consider married and cohabiting couples among individuals between 25 and 59 years old. We follow the paper Greenwood et al. (2014) to calculate the incidence of assortative mating in the region. First, the fraction of couples with the same education level for each region is computed as the actual matching. Secondly, we create a contingency table where the diagonal contains the randomly matched couples where both partners have the same education level. The sum along the diagonal defines the random matching. The ratio of the actual to random matches yields the values for assortative mating by educational status. We proceed analogously to compute assortative mating in terms of occupation. The lowest level of assortative mating is 1 when the actual matching coincides with the random matching. The higher is assortative mating, the more couples sort according to their education or occupation level. We use this measure as a proxy for regional socioeconomic segregation. We use the countries where the information on the socio-economic status of the partner is available in the IPUMS data. We compute the assortative mating in the regions at the NUTS 2 level for these countries: Austria, Greece, Italy, Spain, and Portugal in the year 2001; for Ireland, Poland and Slovenia in 2002; for France in 2006; and lastly for Switzerland in 2000. The sample size of the regions in the IPUMS data ranges from 1,959 to around 1 million couples, with an average of 61 thousand couples per region.

To calculate assortative mating by educational status, we classify the education level in four categories: less than primary level of education completed; primary level of education completed; secondary level of education completed; and university level education completed. We also compute assortative mating in terms of occupational status. We use the classification of occupations based on skill levels. ISCO-08 describes four levels of aggregation which is listed in Table 2. Managers and Professionals (ISCO-08 major groups 1 and 2) are considered to be at the highest skill level 4 . Techni- 
Table 1: Summary Statistics

\begin{tabular}{lcccc}
\hline \hline & mean & sd & min & max \\
\hline Preferences for Redistribution & 3.975 & 0.989 & 1 & 5 \\
Native-born & 0.904 & 0.294 & 0 & 1 \\
Living with partner & 0.630 & 0.483 & 0 & 1 \\
Male & 0.480 & 0.500 & 0 & 1 \\
Age & 42.225 & 13.254 & 18 & 65 \\
Household size & 3.043 & 1.415 & 1 & 15 \\
Primary Education & 0.296 & 0.457 & 0 & 1 \\
Secondary Education & 0.413 & 0.492 & 0 & 1 \\
Tertiary Education & 0.291 & 0.454 & 0 & 1 \\
Employed & 0.634 & 0.482 & 0 & 1 \\
Student & 0.071 & 0.257 & 0 & 1 \\
Unemployed & 0.075 & 0.264 & 0 & 1 \\
Retired & 0.089 & 0.285 & 0 & 1 \\
Other & 0.124 & 0.330 & 0 & 1 \\
Big city & 0.203 & 0.402 & 0 & 1 \\
Suburbs of big city & 0.271 & 0.444 & 0 & 1 \\
Small city & 0.113 & 0.317 & 0 & 1 \\
Village & 0.413 & 0.492 & 0 & 1 \\
Living in comfort on present income & 0.296 & 0.456 & 0 & 1 \\
Coping on present income & 0.477 & 0.499 & 0 & 1 \\
Difficult on present income & 0.227 & 0.419 & 0 & 1 \\
Political Ideology & 4.889 & 2.138 & 0 & 10 \\
Unemployment Rate & 8.878 & 5.921 & 1.8 & 25 \\
Tertiary Educ. Attainment & 19.082 & 8.883 & 5 & 44 \\
Gini before taxes & 0.487 & 0.050 & 0.370 & 0.576 \\
Gdp per capita & & & & \\
$N$ & 32161.045 & 13265.155 & 10512 & 68328 \\
\hline \hline
\end{tabular}


Table 2: ISCO-08 Major Groups and Skill Levels

\begin{tabular}{lc}
\hline \hline & Skill Level \\
\hline 1 Managers & 4 \\
2 Professionals & 4 \\
3 Technicians and Associate Professionals & 3 \\
4 Clerks & 2 \\
5 Services and Sales Workers & 2 \\
6 Skilled Agricultural and Fishery Workers & 2 \\
7 Craft and Related Trades Workers & 2 \\
8 Plant and Machine Operators, and Assemblers & 2 \\
9 Elementary Occupations & 1 \\
\hline \hline
\end{tabular}

Source: Adaptation of Table 1 from International Labour Office (ILO) (2012).

Available at www.ilo.org

cians and Associate Professionals (ISCO-08 major group 3) belongs to the medium-high skill level 3. ISCO-08 major groups 4, 5, 6, 7 and 8 include occupations at the same medium -low skill level 2. Elementary occupations (ISCO-08 major group 9) comprises occupations at the lowest skill level 1. We exclude armed forces from the analysis.

In a further analysis, we compute alternative measures of assortative mating. First, we classify education levels in two categories only: less than primary level of education completed, and at least primary level completed. This index of assortative mating measures segregation of the bottom group of individuals in terms of education. Similarly, we classify education in less than tertiary education and tertiary education level, to measure segregation of the top group of individuals in education terms. We do similarly with occupation levels. In this case, the top occupations are the managers and professionals (ISCO-08 codes 1 and 2) whereas the occupations at the bottom are the elementary occupations (ISCO-08 code 9).

Table 3 provides descriptive statistics of the assortative mating variables 
used in the analysis. These measures are also represented in Figures 1 to 6 . Assortative mating by education ranges from 1.08 to 2.12 ; assortative mating by occupation ranges between 1.20 and 1.61. The level of assortative mating decreases when we use extreme segregation measures (less than primary education, tertiary degree, top and bottom occupations). In general, there is significant heterogeneity of assortative mating within countries as it can be seen from Figures 1 to 6 . Portugal and Greece have large values for education assortative mating, while Switzerland and Slovenia have low values.

Table 3: Descriptive Statistics of Assortative Mating Variables

\begin{tabular}{lcccc}
\hline \hline & mean & sd & $\min$ & $\max$ \\
\hline Assortative Mating by Education & 1.513 & 0.260 & 1.082 & 2.124 \\
Assortative Mating by Occupation & 1.385 & 0.083 & 1.201 & 1.609 \\
Assortative Mating by Less than Primary & 1.086 & 0.155 & 1.000 & 1.560 \\
Assortative Mating by Tertiary Degree & 1.134 & 0.083 & 1.034 & 1.496 \\
Assortative Mating by Top Occupations & 1.188 & 0.060 & 1.082 & 1.302 \\
Assortative Mating by Bottom Occupations & 1.129 & 0.067 & 1.045 & 1.404 \\
\hline \hline
\end{tabular}

The first column in Table 4 shows the correlations between the assortative mating measures and inequality measured as the Gini coefficient before taxes. Assortative mating is positively correlated with inequality as expected. A

Table 4: Correlations between Inequality and Assortative Mating

\begin{tabular}{lcccccc}
\hline \hline & $\begin{array}{c}(1) \\
\text { Gini Before } \\
\text { Tax }\end{array}$ & $\begin{array}{c}(2) \\
\text { AM by } \\
\text { Education }\end{array}$ & $\begin{array}{c}(3) \\
\text { AM by } \\
\text { Tertiary }\end{array}$ & $\begin{array}{c}(4) \\
\text { AM by Less } \\
\text { than Primary }\end{array}$ & $\begin{array}{c}(5) \\
\text { AM by } \\
\text { Occupation }\end{array}$ & $\begin{array}{c}\text { AM by } \\
\text { Top Occ. }\end{array}$ \\
\hline AM by Education & 0.5050 & 1.0000 & & & & \\
AM by Tertiary Degree & 0.0440 & 0.4329 & 1.0000 & & & \\
AM by Less than Primary & 0.2980 & 0.5161 & -0.0285 & 1.0000 & & \\
AM by Occupation & 0.2640 & 0.4664 & 0.2018 & 0.0538 & 1.0000 & \\
AM by Top Occ. & 0.1843 & 0.5258 & 0.0870 & 0.0506 & 0.8424 & 1.0000 \\
AM by Bottom Occ. & 0.4643 & 0.3480 & -0.2415 & 0.7071 & 0.0173 & -0.1415 \\
\hline \hline
\end{tabular}


Figure 1: Assortative Mating by Educational Status

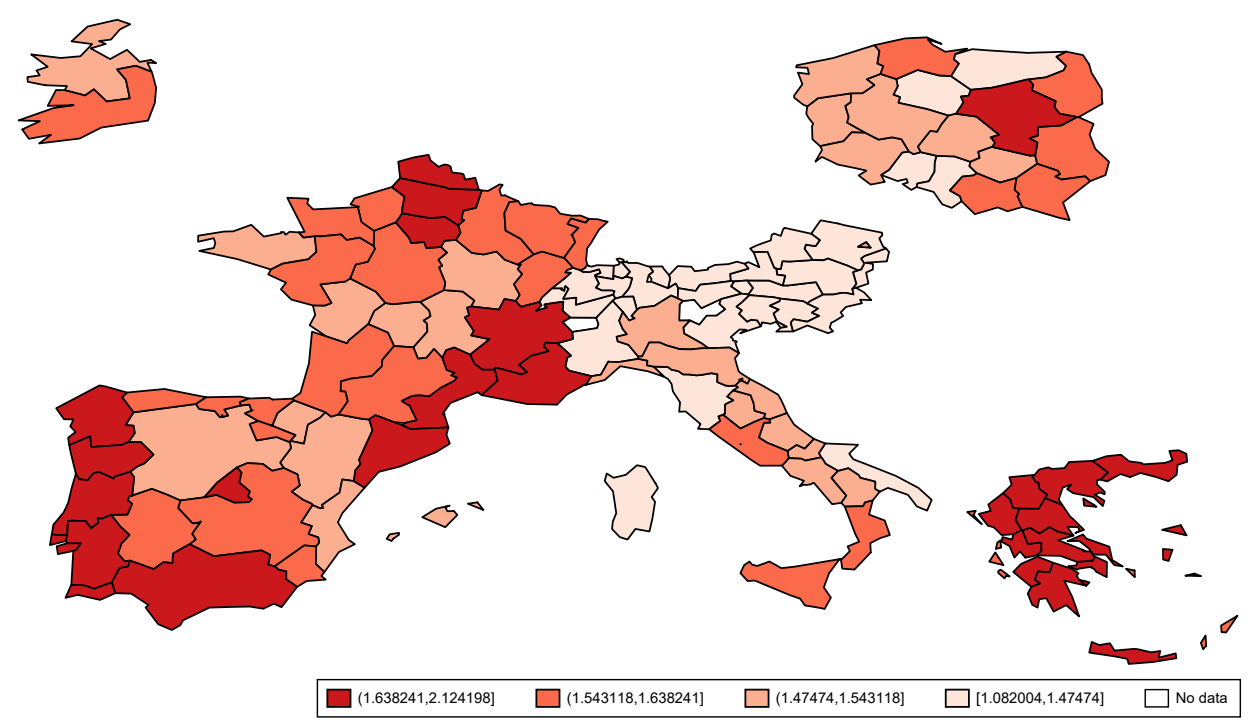

Figure 2: Assortative Mating by Occupational Status

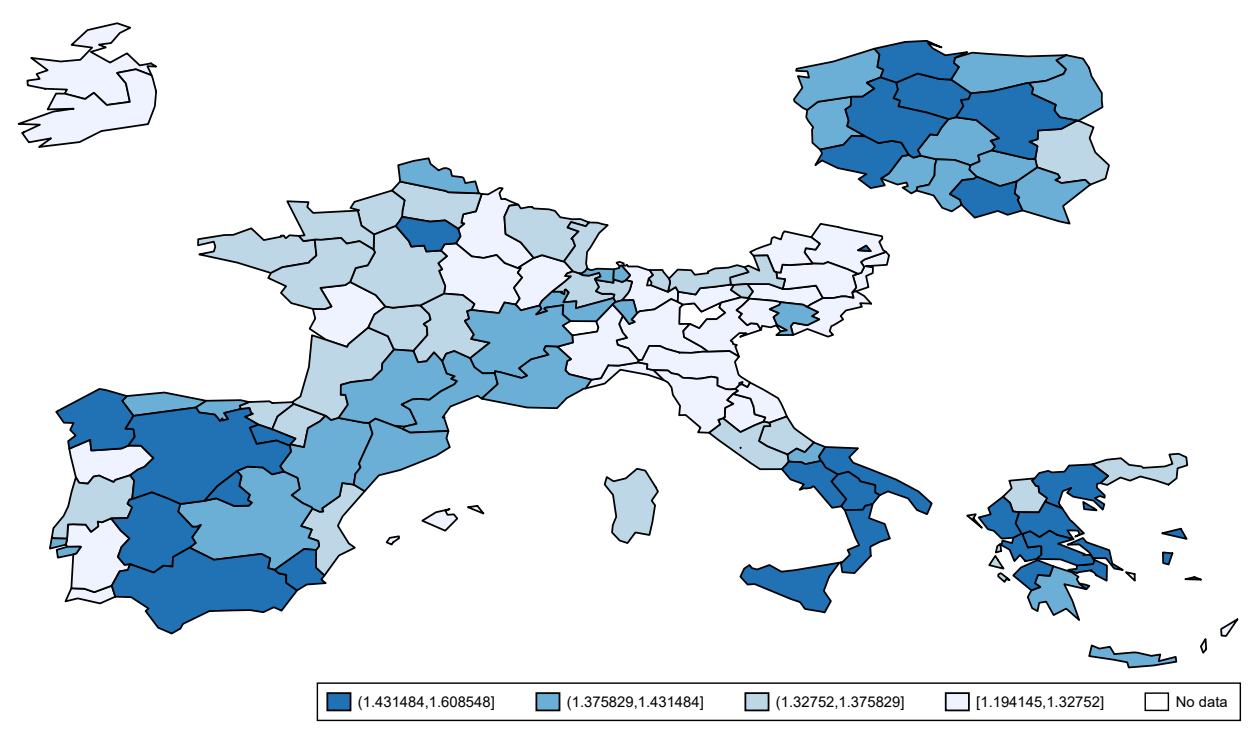


Figure 3: Assortative Mating by Less than Primary Degree

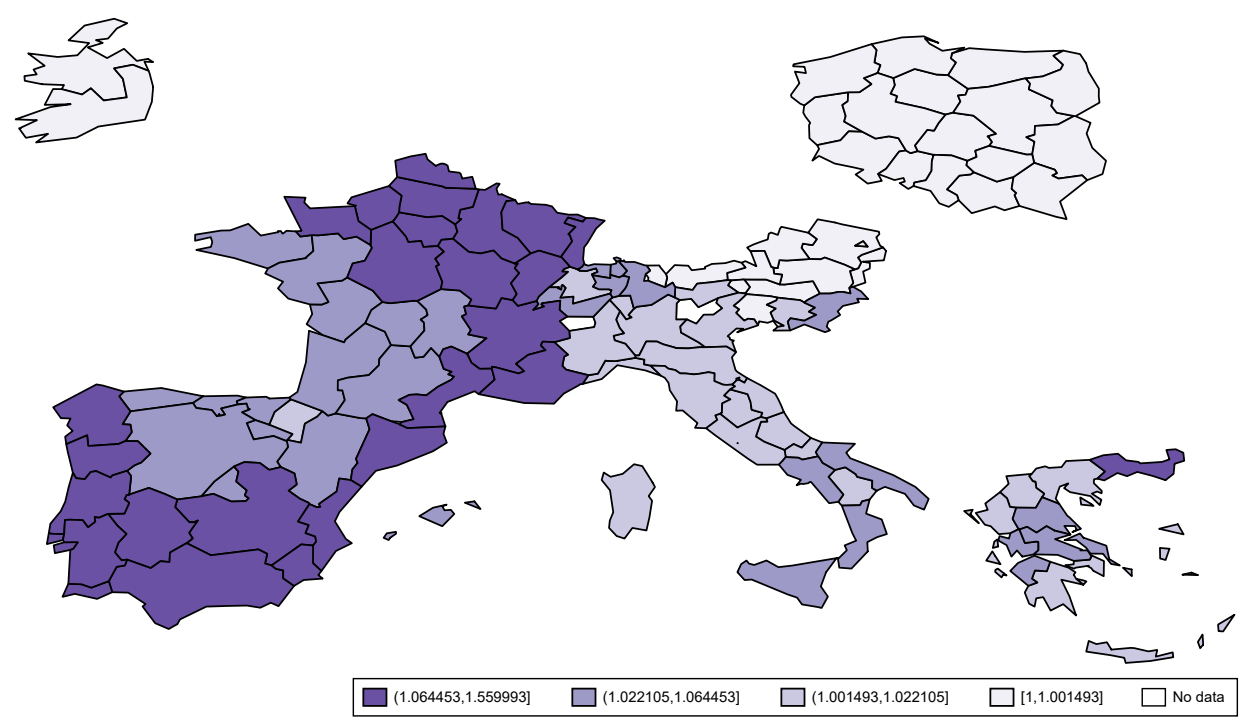

Figure 4: Assortative Mating by Tertiary Degree

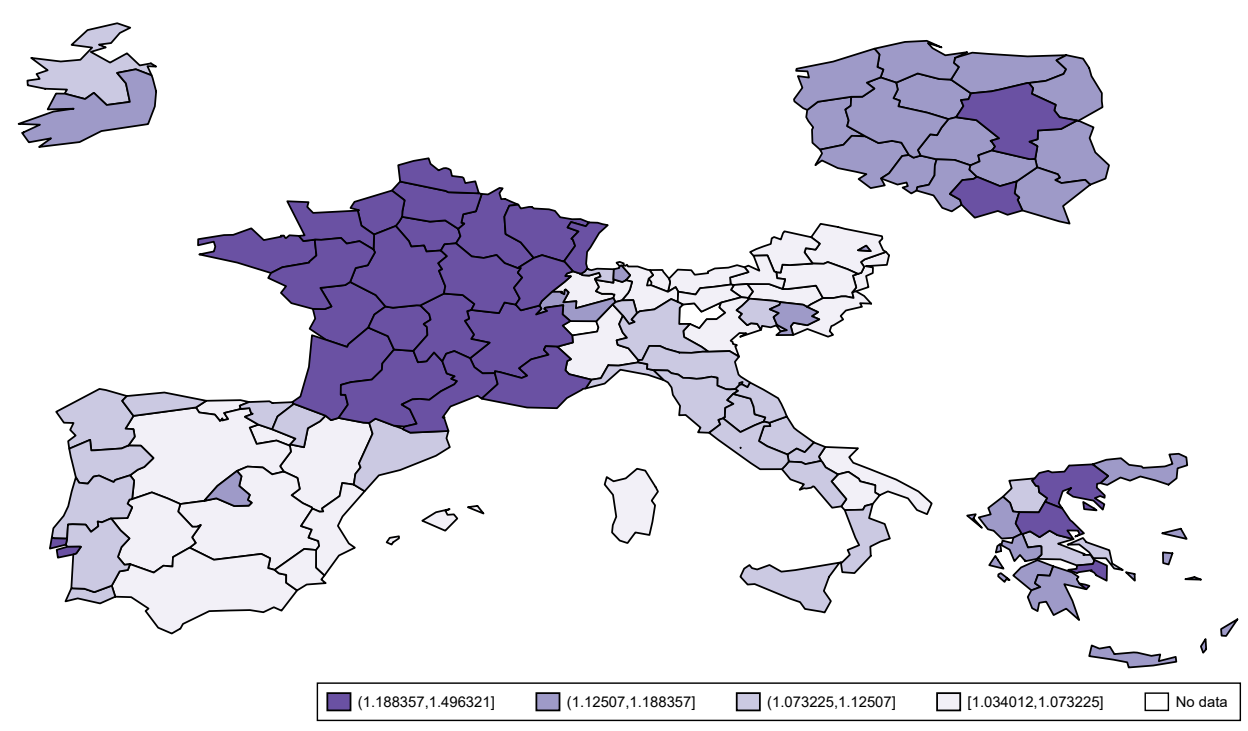


Figure 5: Assortative Mating by Top Occupations

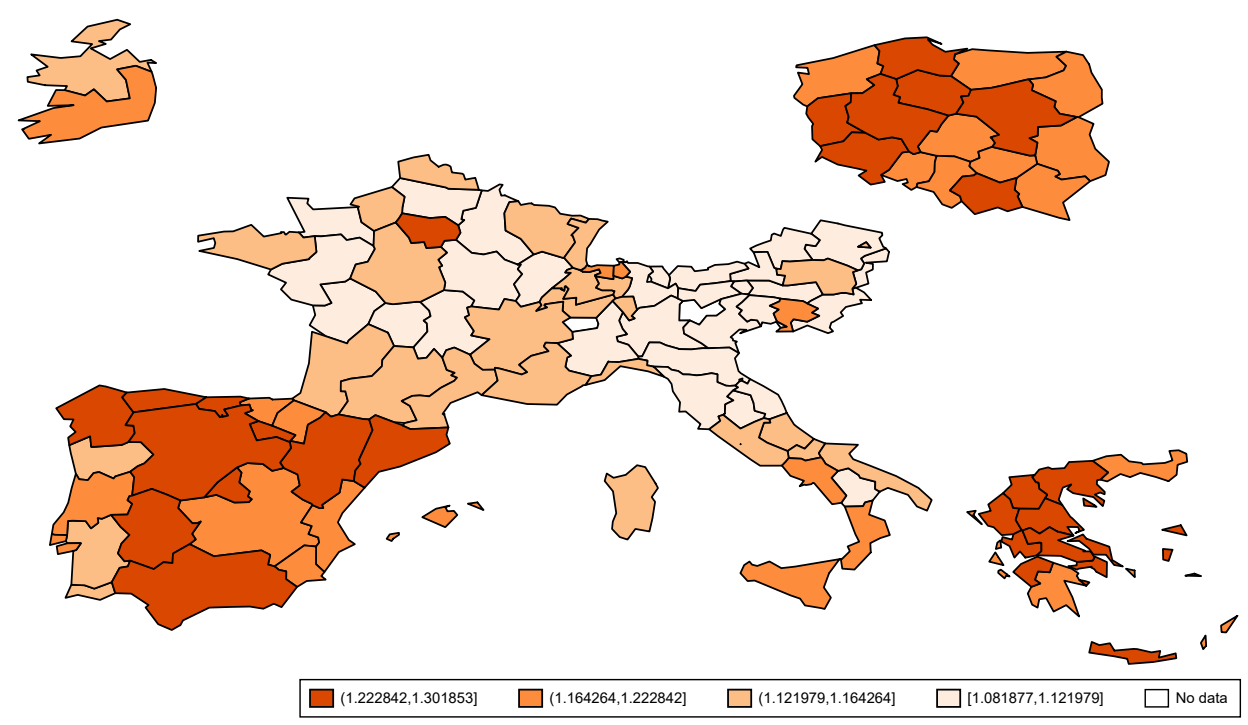

Figure 6: Assortative Mating by Bottom Occupations

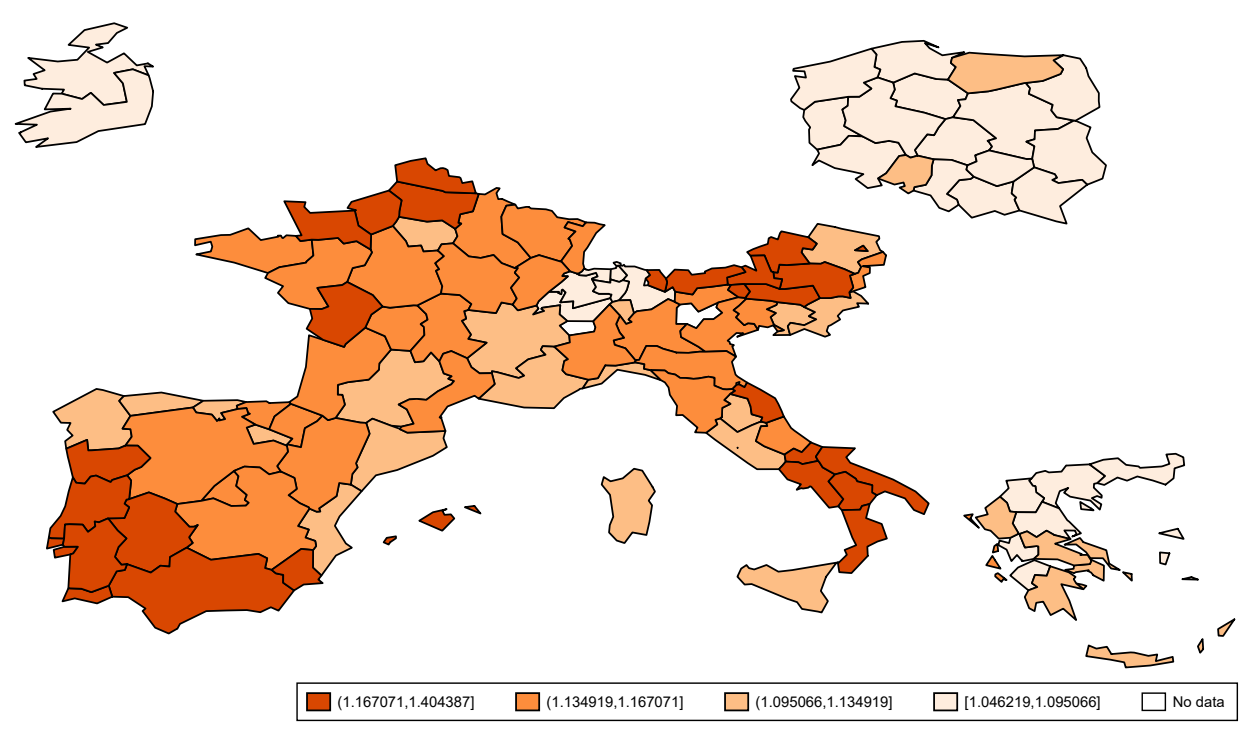


segregated society is likely to have high inequality, and an unequal society is likely to get segregated as discussed in the introduction. Columns (2) to (6) show the correlation between different measures of assortative mating. Assortative mating by education and by occupation are positively correlated, although the correlation is far from perfect. Assortative mating by education is driven by both, segregation at the top and at the bottom as the correlation shows. Assortative mating by occupation is largely reflecting segregation of the affluent (those in top occupations). The measures of assortative mating at the top and at the bottom level are negatively correlated. This suggests that segregation tends to occur either at the top or the bottom of the distribution, rather that both at once, specially for occupation assortative mating.

\subsection{Econometric specification}

We estimate an OLS regression where the dependent variable $y_{\text {inct }}$ measures the preferences for redistribution of an individual $i$ living in region $n$ of country $c$, at survey round $t$. We estimate the following specification for each dimension of assortative mating.

$$
y_{\text {inct }}=\beta A M_{n}+X_{i t} \delta+Z_{n} \gamma+\alpha_{c}+\mu_{t}+\epsilon_{\text {inct }} .
$$

$A M_{n}$ is the measure of assortative mating of region $n$. The vector $X_{i t}$ contains the individuals' characteristics such as age, age squared, gender, partnership status, nativity, highest level of education, main activity in the last seven days (before the interview), the number of people living in the household, the area where respondent's live (big city, suburbs, small city, village), a subjective evaluation of household income (living comfortably, coping, difficult or very difficult to live on present income), and the political ideology of the respondent (0-left, 10-right). All the individual characteristics are from the ESS. The vector $Z_{n}$ controls for regional characteristics, which consists of the regional unemployment rate, the percentage of tertiary educational attainment level, the Gini index, and regional GDP per capita. We include country and year dummies to capture country $\left(\alpha_{c}\right)$ and year 
fixed effects $\left(\mu_{t}\right)$ which are highly significant for all specifications. Finally, $\epsilon_{\text {int }}$ is the error term. We cluster the standard errors at the regional level. All observations are weighted in accordance with the design weights and the population size weights from the European Social Survey.

The main variable of interest is the incidence of assortative mating, which is used as a measure of segregation of the society. Segregation through mating is expected to have a negative effect on the preferences for redistribution as discussed in the introduction. We first estimate the equation for the whole sample. Then we distinguish three sub-samples according to the subjective income level of individuals: those that report living comfortably on present income, those that report coping on present income, and those that report that they have difficulties living on present income. ${ }^{3}$ A negative effect of assortative mating on preferences for redistribution in all sub-samples would provide support for the mechanism proposed in Windsteiger (2017), while a negative effect only for the affluent sample would provide support for Bjorvatn and Cappelen (2003)'s theory.

\section{Results}

\subsection{Main results}

We analyze the effect of segregation, measured as the incidence of assortative mating, on preferences for redistribution. In Table 5, we estimate how assortative mating in terms of education affects an individual's support for redistribution. The first column reports the result for the whole sample, while columns (2) to (4) report the results for three sub-samples based on

\footnotetext{
${ }^{3}$ We use the subjective income evaluation to have comparable values across waves. An alternative would be to use the reported income deciles. However, the classification of income deciles in rounds 1-3 of the ESS data set is different from the classification in the rounds 4 to 8 , and it is not possible to combine them. Not to lose observations, we decided to divide the sample according to respondents' subjective evaluation of income instead of income deciles. Both measures are strongly correlated (Correlation is 0.52).
} 
subjective income. Column 2 refers to the sample of those that report living comfortably with current income, column 3 refers to those who consider that they are coping on present income, and column 4 refers to those who have difficulties with their present income. Each column includes country and year fixed effects, regional controls, basic-individual characteristics, and a political-ideology control variable.

Results reveal that segregation affects negatively preferences for redistribution only for those individuals who live comfortably on present income. The coefficient for the whole sample is negative but not statistically significant. Once we distinguish between different income level groups, the effect of assortative mating on preferences for redistribution becomes negative and significant for the affluent group, while it has no significant effect for the rest. Table 6 shows similar results when segregation is measured as assortative mating by occupation. The more couples with the same occupation are in the region, the less support for redistribution is given by individuals who live comfortably with their income.

These results suggest that the effect of segregation on attitudes towards redistribution is negative for the wealthier individuals only. This is consistent with the theory where the wealthy may be less willing to redistribute due to their lower social attachment in the presence of high segregation (Bjorvatn and Cappelen, 2003).

Tables 7 and 8 report the effects of extreme segregation at the top and the bottom of the society in terms of education and occupation levels, respectively. In the upper panel of Table 7, we measure assortative mating in terms of having less than a primary education degree. ${ }^{4}$ In the lower panel, assortative mating is measured by having a completed tertiary degree. In the former case, we find that segregation of those at the bottom in terms of education has a negative effect for the whole sample. This result is driven by the group of wealthy individuals, as the coefficient of assortative mating

\footnotetext{
${ }^{4}$ In this estimation, Austria and Ireland are not included because all individuals completed at least a primary degree education in these countries.
} 
Table 5: Assortative Mating by Educational Status and Support for Redistribution

\begin{tabular}{lcccc}
\hline \hline & $(1)$ & $(2)$ & $(3)$ & $(4)$ \\
& All sample & $\begin{array}{c}\text { Living comfortably } \\
\text { on present income }\end{array}$ & $\begin{array}{c}\text { Coping on } \\
\text { present income }\end{array}$ & $\begin{array}{c}\text { Difficulties with } \\
\text { present income }\end{array}$ \\
\hline Assortative Mating & -0.006 & $\mathbf{- 0 . 3 9 6 * *}$ & 0.047 & 0.170 \\
by Educational Status & $(0.176)$ & $\mathbf{( 0 . 1 9 5 )}$ & $(0.236)$ & $(0.162)$ \\
\hline$N$ & 68341 & 20220 & 32622 & 15499 \\
adj. $R^{2}$ & 0.084 & 0.113 & 0.053 & 0.035 \\
\hline \hline Country and year FE & yes & yes & yes & yes \\
Regional controls & yes & yes & yes & yes \\
Individual controls & yes & yes & yes & yes \\
Ideology controls & yes & yes & yes & yes \\
\hline \hline
\end{tabular}

Notes: OLS estimation. The dependent variable depends on the answers to this survey question: Should the government take measures to reduce differences in income levels? We use eight ESS rounds from 2002 to 2016. The independent variable is assortative mating in terms of education at the regional level (for its computation IPUMS dataset is used). The first column includes the whole sample, column 2 includes the group of individuals who live comfortably on their present income, column 3 includes individuals who cope with their present income and lastly, column 4 includes individuals who have difficulties with their present income. Regional controls contain the unemployment rate and the percentage of tertiary educational attainment level for the year 2001 from Eurostat; Gini before tax and transfers (France, Switzerland, Ireland, Slovenia and Portugal for 2010; Austria, Greece, Italy, Poland, and Spain for the year 2013) and GDP per capita for the year 2001 (source OECD). Individual controls include nativity status, partnership status, gender, age, age squared, education level, the size of household, activity status before interview-i.e., being unemployed, student, retired..etc, individual's domicile-e.g., living in a big city, suburbs, in a small city or a village, feelings about present income-e.g., living in comfort or coping on present income. Ideology control includes attitudes towards the left or right-wing political position. Robust standard errors clustered at the regional level in parentheses. ${ }^{*} p<0.10$, ${ }^{* *} p<0.05,{ }^{* * *} p<0.01$. 
Table 6: Assortative Mating by Occupational Status and Support for Redistribution

\begin{tabular}{lcccc}
\hline \hline & $(1)$ & $(2)$ & $(3)$ & $(4)$ \\
& All sample & $\begin{array}{c}\text { Living comfortably } \\
\text { on present income }\end{array}$ & $\begin{array}{c}\text { Coping on } \\
\text { present income }\end{array}$ & $\begin{array}{c}\text { Difficulties with } \\
\text { present income }\end{array}$ \\
\hline Assortative Mating & -0.163 & $\begin{array}{c}\mathbf{- 0 . 7 4 5 * *} \\
\mathbf{( 0 . 2 4 2 )}\end{array}$ & 0.088 & 0.007 \\
by Occupational Status & $(0.194)$ & $(0.272)$ & $(0.229)$ \\
\hline$N$ & 68341 & 20220 & 32622 & 15499 \\
adj. $R^{2}$ & 0.084 & 0.113 & 0.053 & 0.035 \\
\hline \hline Country and year FE & yes & yes & yes & yes \\
Regional controls & yes & yes & yes & yes \\
Individual controls & yes & yes & yes & yes \\
Ideology controls & yes & yes & yes & yes \\
\hline \hline
\end{tabular}

Notes: The OLS estimation includes country fixed effects and year fixed effects, regional controls, individual controls and ideology controls (see the notes of Table 5 for details). The independent variable is assortative mating in terms of occupation at the regional level. Robust standard errors clustered at the regional level in parentheses. ${ }^{*} p<0.10,{ }^{* *}$ $p<0.05,{ }^{* * *} p<0.01$. 
is only significant for this sub-sample. In contrast, results in the lower panel show that segregation of individuals at the top of the education ladder is not affecting preferences for redistribution of individuals.

In Table 8, we report the results when using assortative mating at the top and the bottom occupation level. According to the skill level classification, the top occupations are the managers and professionals (ISCO-08 codes 1 and 2) whereas the occupations at the bottom are the elementary occupations (ISCO-08 code 9 ). In this case, the coefficient of assortative mating by top occupations is negative and significant for the whole sample. As before, this result is driven by the wealthiest sub-sample of individuals. In contrast, when the assortative mating is computed as bottom versus other occupations, the coefficient is insignificant for all sub-samples.

The rest of the results are consistent with the existing literature. Table A1 in the Appendix presents the coefficients for the individual characteristics. Being native-born is positively associated with the demand for redistribution. Highly educated individuals are less likely to demand redistribution. The literature explains this significant and negative coefficient with prospects for upward mobility. Individuals invest more in education to have upward mobility in the future. We also find that men are more inclined to disapprove of redistribution than women. Compared to employed individuals, retired and unemployed individuals are more likely to support shared prosperity, whereas students are averse to it. Furthermore, individuals who live in a small city or a village tend to vote for more redistribution than individuals living in a big city. Ideologically, left-wing individuals are more likely to be egalitarians. Accordingly, they are more inclined to embrace the government's role in reducing income inequality than right-wing individuals. Finally, we use the individuals' perception of their income level as a proxy for income. The more individuals consider that their current income is not sufficient for living, the more they tend to support redistribution. 
Table 7: Assortative Mating by Top and Bottom Educational Degree and Support for Redistribution

\begin{tabular}{lcccc}
\hline \hline & $(1)$ & $(2)$ & $(3)$ & $(4)$ \\
& All sample & $\begin{array}{c}\text { Living comfortably } \\
\text { on present income }\end{array}$ & $\begin{array}{c}\text { Coping on } \\
\text { present income }\end{array}$ & $\begin{array}{c}\text { Difficulties with } \\
\text { present income }\end{array}$ \\
\hline Assortative Mating by & $\mathbf{- 0 . 5 6 6 ^ { * * }}$ & $\mathbf{- 1 . 5 1 \mathbf { * } ^ { * * }}$ & -0.021 & -0.304 \\
Less than Primary Educ & $\mathbf{( 0 . 2 4 0 )}$ & $\mathbf{( 0 . 3 6 1 )}$ & $(0.353)$ & $(0.340)$ \\
$N$ & 56119 & 15660 & 26736 & 13723 \\
adj. $R^{2}$ & 0.085 & 0.118 & 0.054 & 0.034 \\
\hline Assortative Mating by & -0.644 & -0.703 & -0.637 & -0.946 \\
Tertiary Degree & $(0.395)$ & $(0.506)$ & $(0.560)$ & $(0.591)$ \\
$N$ & 68341 & 20220 & 32622 & 15499 \\
adj. $R^{2}$ & 0.084 & 0.113 & 0.054 & 0.036 \\
\hline \hline Country and year FE & yes & yes & yes & yes \\
Regional controls & yes & yes & yes & yes \\
Individual controls & yes & yes & yes & yes \\
Ideology controls & yes & yes & yes & yes \\
\hline \hline
\end{tabular}

Notes: The OLS estimation includes country fixed effects and year fixed effects, regional controls, individual controls and ideology controls (see the notes of Table 5 for details). In the upper panel of the table, we compute assortative mating in terms of having a completed educational degree. In the lower panel, assortative mating is measured by having a completed tertiary degree. The value of assortative mating by degree is 1 in Austria and Ireland because all individuals completed at least a primary degree education. Therefore, the sample does not include the countries Austria and Ireland in the first estimation. Robust standard errors clustered at the regional level in parentheses. ${ }^{*} p<$ $0.10,{ }^{* *} p<0.05,{ }^{* * *} p<0.01$. 
Table 8: Assortative Mating by Top and Bottom Occupations and Support for Redistribution

\begin{tabular}{lcccc}
\hline \hline & $(1)$ & $(2)$ & $(3)$ & $(4)$ \\
& All sample & $\begin{array}{c}\text { Living comfortably } \\
\text { on present income }\end{array}$ & $\begin{array}{c}\text { Coping on } \\
\text { present income }\end{array}$ & $\begin{array}{c}\text { Difficulties with } \\
\text { present income }\end{array}$ \\
\hline Assortative Mating by & $\mathbf{- 0 . 5 7 \mathbf { 1 } ^ { * }}$ & $\mathbf{- 0 . 9 0 8 * *}$ & -0.265 & -0.569 \\
Top Occupations & $\mathbf{( 0 . 2 8 8 )}$ & $\mathbf{( 0 . 3 8 4 )}$ & $(0.415)$ & $(0.409)$ \\
$N$ & 68341 & 20220 & 32622 & 15499 \\
adj. $R^{2}$ & 0.084 & 0.113 & 0.054 & 0.035 \\
\hline Assortative Mating by & 0.008 & -0.624 & 0.186 & 0.306 \\
Bottom Occupations & $(0.256)$ & $(0.456)$ & $(0.327)$ & $(0.354)$ \\
$N$ & 68341 & 20220 & 32622 & 15499 \\
adj. $R^{2}$ & 0.084 & 0.113 & 0.054 & 0.035 \\
\hline \hline Country and year FE & yes & yes & yes & yes \\
Regional controls & yes & yes & yes & yes \\
Individual controls & yes & yes & yes & yes \\
Ideology controls & yes & yes & yes & yes \\
\hline \hline
\end{tabular}

Notes: The OLS estimation includes country fixed effects and year fixed effects, regional controls, individual controls and ideology controls (see the notes of Table 5 for details). The first regression includes the main independent variable of assortative mating by the top occupations that are managers and professionals (ISCO-08 codes 1 and 2). In the second estimation, the main independent variable is assortative mating by bottom occupations that are elementary occupations (ISCO-08 code 9). Robust standard errors clustered at the regional level in parentheses. ${ }^{*} p<0.10,{ }^{* *} p<0.05,{ }^{* * *} p<0.01$. 


\subsection{Robustness and placebo exercise}

We perform a robustness exercise by using an alternative variable measuring preferences for redistribution. We use the information on to which extent the respondents agree or disagree with the following statements: "Large differences in income are acceptable to reward talents and efforts", "For fair society, differences in standard of living should be small", and "Social services cost businesses too much in taxes", which are available in the special modules on welfare attitudes from the waves 2008 and 2016 of the ESS. We perform a principal component analysis (PCA) using these variables and our previous measure of preferences for redistribution, which was based on the statement: "The government should take measures to reduce differences in income levels". We take the first component of the PCA as an alternative measure of preferences for redistribution.

We then redo the previous analysis with this new measure as the dependent variable. Results are reported in Table A2 in the Appendix. Although the sample size is smaller (only two waves are used in this analysis), results are similar to the ones found in the main analysis. The negative relationship between segregation and preferences for redistribution is confirmed when segregation is measured as assortative mating by occupation, as well as assortative mating in bottom education and top occupation levels. Moreover, these results are driven by the affluent individuals sub-sample. Only the assortative mating by education does not come significant. Note also that, unlike the previous results, individuals who cope with their present income are likely to demand less redistribution when assortative mating is computed in terms of having less than a primary degree.

For the last part of the analysis, we run a placebo test. We use survey questions from the ESS that we believe should not be affected by segregation. In particular we use respondents' opinions about the importance to care for nature and environment, to be humble and modest, and to think new ideas and being creative. We redo the previous analysis using these dependent variables separately. If we found some significant effect, then the previous 
results on preferences for redistribution could be spurious. Results are reported in table A3 in the Appendix. The different measures of assortative mating have no significant effect on any of the previous variables as expected.

\section{Conclusion}

This paper shows that segregation and preferences for redistribution are negatively related. The incidence of assortative mating in terms of education and occupation is used as a proxy to measure socioeconomic segregation in a region. Increased segregation in most forms of assortative mating leads the affluent to support less redistribution. These results are consistent with the paper of Bjorvatn and Cappelen (2003), who argue that in a segregated society with large inequalities in pre-tax income distribution, the affluent become more detached from the other groups in the society and are less keen on supporting the redistributive policies. 


\section{A Appendix}

Table A1: Individual Characteristics

\begin{tabular}{|c|c|c|}
\hline & Educational & Occupational \\
\hline \multirow[t]{2}{*}{ Assortative Mating } & -0.004 & -0.158 \\
\hline & $(0.176)$ & $(0.195)$ \\
\hline \multirow[t]{2}{*}{ Native-born } & $0.038^{*}$ & $0.038^{*}$ \\
\hline & $(0.020)$ & $(0.020)$ \\
\hline \multirow[t]{2}{*}{ Living with partner } & -0.008 & -0.008 \\
\hline & $(0.017)$ & $(0.017)$ \\
\hline \multirow[t]{2}{*}{ Male } & $-0.113^{* * *}$ & $-0.113^{* * *}$ \\
\hline & $(0.011)$ & $(0.011)$ \\
\hline \multirow[t]{2}{*}{ Age } & 0.001 & 0.001 \\
\hline & $(0.004)$ & $(0.004)$ \\
\hline \multirow[t]{2}{*}{ Age2/100 } & 0.001 & 0.001 \\
\hline & $(0.005)$ & $(0.005)$ \\
\hline \multirow[t]{2}{*}{ Secondary Education } & -0.005 & -0.005 \\
\hline & $(0.016)$ & $(0.016)$ \\
\hline \multirow[t]{2}{*}{ Tertiary Education } & $-0.198 * * *$ & $-0.198 * * *$ \\
\hline & $(0.026)$ & $(0.026)$ \\
\hline \multirow[t]{2}{*}{ Student } & $-0.110 * * *$ & $-0.111^{* * *}$ \\
\hline & $(0.028)$ & $(0.028)$ \\
\hline \multirow[t]{2}{*}{ Unemployed } & $0.041^{* *}$ & $0.042^{* *}$ \\
\hline & $(0.019)$ & $(0.019)$ \\
\hline \multirow[t]{2}{*}{ Retired } & $0.110 * * *$ & $0.110 * * *$ \\
\hline & $(0.021)$ & $(0.021)$ \\
\hline \multirow[t]{2}{*}{ Other activities } & $-0.034^{* *}$ & $-0.034^{* *}$ \\
\hline & $(0.016)$ & $(0.016)$ \\
\hline
\end{tabular}

Continued on next page... 
Table A1 (continued): Individual Characteristics

\begin{tabular}{|c|c|c|}
\hline & Educational & Occupational \\
\hline \multirow[t]{2}{*}{ Household size } & 0.000 & 0.000 \\
\hline & $(0.005)$ & $(0.006)$ \\
\hline \multirow[t]{2}{*}{ Suburbs of big city } & 0.043 & 0.043 \\
\hline & $(0.028)$ & $(0.028)$ \\
\hline \multirow[t]{2}{*}{ Small city } & $0.084^{* * *}$ & $0.083^{* * *}$ \\
\hline & $(0.026)$ & $(0.026)$ \\
\hline \multirow[t]{2}{*}{ Village } & $0.098 * * *$ & $0.098 * * *$ \\
\hline & $(0.028)$ & $(0.028)$ \\
\hline \multirow[t]{2}{*}{ Coping on present income } & $0.209 * * *$ & $0.208^{* * *}$ \\
\hline & $(0.020)$ & $(0.020)$ \\
\hline \multirow[t]{2}{*}{ Difficult on present income } & $0.341^{* * *}$ & $0.341^{* * *}$ \\
\hline & $(0.026)$ & $(0.026)$ \\
\hline \multirow[t]{2}{*}{ Political Ideology } & $-0.064 * * *$ & $-0.063 * * *$ \\
\hline & $(0.007)$ & $(0.007)$ \\
\hline \multirow[t]{2}{*}{ Gdp per capita } & $-0.000 * * *$ & $-0.000 * * *$ \\
\hline & $(0.000)$ & $(0.000)$ \\
\hline \multirow[t]{2}{*}{ Unemployment rate } & 0.002 & 0.003 \\
\hline & $(0.005)$ & $(0.005)$ \\
\hline \multirow[t]{2}{*}{ Tertiary education attainment } & $0.006^{*}$ & $0.008 * *$ \\
\hline & $(0.003)$ & $(0.003)$ \\
\hline \multirow[t]{2}{*}{ Gini before tax } & -0.556 & -0.388 \\
\hline & $(0.565)$ & $(0.540)$ \\
\hline \multirow[t]{2}{*}{ _cons } & $4.322^{* * *}$ & $4.420^{* * *}$ \\
\hline & $(0.273)$ & $(0.302)$ \\
\hline$N$ & 68341 & 68341 \\
\hline adj. $R^{2}$ & 0.084 & 0.084 \\
\hline
\end{tabular}


Table A2: Index of Welfare Attitudes

\begin{tabular}{|c|c|c|c|c|}
\hline $\begin{array}{l}\text { Dependent variable: } \\
\text { Index of Welfare Attitudes }\end{array}$ & & & & \\
\hline Independent variable: & All sample & $\begin{array}{l}\text { Living comfortably } \\
\text { on present income }\end{array}$ & $\begin{array}{c}\text { Coping on } \\
\text { present income }\end{array}$ & $\begin{array}{l}\text { Difficulties with } \\
\text { present income }\end{array}$ \\
\hline \multirow{2}{*}{ Assortative Mating by Education } & -0.403 & -0.605 & -0.554 & -0.194 \\
\hline & $(0.322)$ & $(0.519)$ & $(0.335)$ & $(0.534)$ \\
\hline \multirow[t]{2}{*}{ Ass. Mating by Less than Primary } & $-1.197 * * *$ & $-1.383^{*}$ & $-1.000^{*}$ & -1.096 \\
\hline & $(0.423)$ & $(0.817)$ & $(0.527)$ & $(0.910)$ \\
\hline \multirow[t]{2}{*}{ Assortative Mating by Tertiary Degree } & -0.404 & -0.261 & -0.891 & 0.658 \\
\hline & $(-0.77)$ & $(-0.30)$ & $(-1.25)$ & $(0.50)$ \\
\hline \multirow[t]{2}{*}{ Assortative Mating by Occupation } & $-0.857 * *$ & $-1.784^{* * *}$ & -0.533 & -0.476 \\
\hline & $(0.334)$ & $(0.484)$ & $(0.374)$ & $(0.756)$ \\
\hline
\end{tabular}

Continued on next page... 
Table A2 (continued): Index of Welfare Attitudes

\begin{tabular}{|c|c|c|c|c|}
\hline \multicolumn{5}{|l|}{$\begin{array}{l}\text { Dependent variable: } \\
\text { Index of Welfare Attitudes }\end{array}$} \\
\hline Independent variable: & All sample & $\begin{array}{l}\text { Living comfortably } \\
\text { on present income }\end{array}$ & $\begin{array}{c}\text { Coping on } \\
\text { present income }\end{array}$ & $\begin{array}{l}\text { Difficulties with } \\
\text { present income }\end{array}$ \\
\hline \multirow{2}{*}{ Assortative Mating by Top Occupations } & $-1.279 *$ & $-2.695 * * *$ & -0.766 & -0.344 \\
\hline & $(0.673)$ & $(0.944)$ & $(0.728)$ & $(1.470)$ \\
\hline \multirow[t]{2}{*}{ Assortative Mating by Bottom Occupations } & 0.120 & 0.258 & 0.145 & -0.196 \\
\hline & $(0.41)$ & $(0.43)$ & $(0.35)$ & $(-0.42)$ \\
\hline$N$ & 16326 & 4888 & 7918 & 3520 \\
\hline Country and year FE & yes & yes & yes & yes \\
\hline Regional controls & yes & yes & yes & yes \\
\hline Individual controls & yes & yes & yes & yes \\
\hline Ideology controls & yes & yes & yes & yes \\
\hline
\end{tabular}

Notes: The OLS estimations are made separately for each assortative mating variable. The dependent variable is constructed as a composite index of attitudes as the first component of a principal component analysis. For this index, the special modules on welfare attitudes from the rounds of 2008 and 2016 of ESS have been used. The rounds inquire in which extent the respondents agree or disagree with the following statements:"The government should take measures to reduce differences in income levels", "Large differences in income acceptable to reward talents and efforts", "For fair society, differences in standard of living should be small", and "Social services cost businesses too much in taxes". Robust standard errors clustered at the regional level in parentheses. ${ }^{*} p<0.10,{ }^{* *} p<0.05,{ }^{* * *} p<0.01$. 
Table A3: Placebo Test

\begin{tabular}{|c|c|c|c|c|}
\hline \multicolumn{5}{|l|}{ "Dependent variable: } \\
\hline Important to care for environment & All sample & $\begin{array}{l}\text { Living comfortably } \\
\text { on present income }\end{array}$ & $\begin{array}{c}\text { Coping on } \\
\text { present income }\end{array}$ & $\begin{array}{l}\text { Difficulties with } \\
\text { present income }\end{array}$ \\
\hline \multirow[t]{2}{*}{ Assortative Mating by Education } & 0.136 & -0.086 & 0.235 & 0.108 \\
\hline & $(0.152)$ & $(0.213)$ & $(0.196)$ & $(0.225)$ \\
\hline \multirow[t]{2}{*}{ Assortative Mating by Occupation } & -0.032 & -0.043 & -0.067 & -0.023 \\
\hline & $(0.199)$ & $(0.215)$ & $(0.256)$ & $(0.286)$ \\
\hline$N$ & 66362 & 19458 & 31719 & 15185 \\
\hline \multicolumn{5}{|l|}{ Dependent variable: } \\
\hline \multicolumn{5}{|c|}{ Important to be humble and modest, not draw attention } \\
\hline \multirow[t]{2}{*}{ Assortative Mating by Education } & -0.022 & -0.139 & -0.065 & 0.300 \\
\hline & $(0.221)$ & $(0.313)$ & $(0.240)$ & $(0.247)$ \\
\hline \multirow[t]{2}{*}{ Assortative Mating by Occupation } & -0.027 & 0.201 & -0.166 & 0.056 \\
\hline & $(0.307)$ & $(0.457)$ & $(0.346)$ & $(0.343)$ \\
\hline$N$ & 66296 & 19431 & 31686 & 15179 \\
\hline
\end{tabular}

Continued on next page... 
Table A3 (continued): Placebo Test

\begin{tabular}{|c|c|c|c|c|}
\hline $\begin{array}{l}\text { Dependent variable: } \\
\text { Important to think new ideas, being creative }\end{array}$ & All sample & $\begin{array}{l}\text { Living comfortably } \\
\text { on present income }\end{array}$ & $\begin{array}{c}\text { Coping on } \\
\text { present income }\end{array}$ & $\begin{array}{l}\text { Difficulties with } \\
\text { present income }\end{array}$ \\
\hline \multirow[t]{2}{*}{ Assortative Mating by Education } & -0.077 & -0.411 & 0.071 & -0.028 \\
\hline & $(0.182)$ & $(0.264)$ & $(0.226)$ & $(0.274)$ \\
\hline \multirow[t]{2}{*}{ Assortative Mating by Occupation } & -0.260 & -0.499 & -0.094 & -0.180 \\
\hline & $(0.234)$ & $(0.303)$ & $(0.333)$ & $(0.413)$ \\
\hline$N$ & 66371 & 19469 & 31726 & 15176 \\
\hline Country and year FE & yes & yes & yes & yes \\
\hline Regional controls & yes & yes & yes & yes \\
\hline Individual controls & yes & yes & yes & yes \\
\hline Ideology controls & yes & yes & yes & yes \\
\hline
\end{tabular}

Notes: The OLS estimations are made separately for each assortative mating variable. Regressions include country fixed effects and year fixed effects, regional controls, individual controls and ideology controls (see the notes of Table 5 for details). Robust standard errors clustered at the regional level in parentheses. ${ }^{*} p<0.10,{ }^{* *} p<0.05,{ }^{* * *} p<0.01$. 


\section{References}

Alesina, A. And G.-M. Angeletos (2005): "Fairness and Redistribution," American Economic Review, 95, 960-980.

Alesina, A. And N. Fuchs-Schündeln (2007): "Goodbye Lenin (or Not?): The Effect of Communism on People's Preferences," American Economic Review, 97, 1507-1528.

Alesina, A. And P. Giuliano (2011): "Chapter 4 - Preferences for Redistribution," in Handbook of Social Economics, ed. by J. Benhabib, A. Bisin, and M. O. Jackson, North-Holland, vol. 1, $93-131$.

Alesina, A., E. Glaeser, And E. L. Glaeser (2004): Fighting poverty in the US and Europe: A world of difference, Oxford University Press.

Alesina, A. And E. La Ferrara (2005): "Preferences for redistribution in the land of opportunities," Journal of Public Economics, 89, 897-931.

Alesina, A., S. Stantcheva, And E. Teso (2018): "Intergenerational Mobility and Preferences for Redistribution," American Economic Review, $108,521-54$.

Benabou, R. And E. A. OK (2001): "Social Mobility and the Demand for Redistribution: The Poum Hypothesis*," The Quarterly Journal of Economics, 116, 447-487.

Bjorvatn, K. And A. Cappelen (2003): "Inequality, segregation, and redistribution," Journal of Public Economics, 87, 1657 - 1679.

Blossfeld, H.-P. (2009): "Educational Assortative Marriage in Comparative Perspective," Annual Review of Sociology, 35, 513-530.

Borge, L.-E. And J. RatTs $\varnothing$ (2004): "Income distribution and tax structure: Empirical test of the Meltzer-Richard hypothesis," European Economic Review, 48, $805-826$. 
Bruch, E. And R. MARE (2009): "Segregation dynamics," in The Oxford handbook of analytical sociology, ed. by P. Bearman and P. Hedström, Oxford University Press.

Corneo, G. And H. P. Grüner (2000): "Social Limits to Redistribution," American Economic Review, 90, 1491-1507.

- (2002): "Individual preferences for political redistribution," Journal of Public Economics, 83, 83 - 107.

Cruces, G., R. Perez-Truglia, and M. Tetaz (2013): "Biased perceptions of income distribution and preferences for redistribution: Evidence from a survey experiment," Journal of Public Economics, 98, 100 - 112.

Cusack, T., T. Iversen, And P. Rehm (2006): "Risks at Work: The Demand and Supply Sides of Government Redistribution," Oxford Review of Economic Policy, 22, 365-389.

European Social Survey (ESS) (2018): "European Social Survey Cumulative File, ESS 1-8 (2018). Data file edition 1.0. NSD," .

Eurostat (2019): "Statistical Office of the European Union, Regional statistics by NUTS classification (Accessed on 9 December 2019)," .

Fernández-Albertos, J. And D. Manzano (2016): "Dualism and support for the welfare state," Comparative European Politics, 14, 349-375.

FinseraAs, H. (2009): "Income Inequality and Demand for Redistribution: A Multilevel Analysis of European Public Opinion," Scandinavian Political Studies, 32, 94-119.

FonG, C. (2001): "Social preferences, self-interest, and the demand for redistribution," Journal of Public Economics, 82, 225 - 246.

Georgiadis, A. And A. Manning (2012): "Spend it like Beckham? Inequality and redistribution in the UK, 1983-2004," Public Choice, 151, 537-563. 
Gouveia, M. And N. A. Masia (1998): "Does the median voter model explain the size of government?: Evidence from the states," Public Choice, 97, 159-177.

Greenwood, J., N. Guner, G. Kocharkov, and C. Santos (2014): "Marry Your Like: Assortative Mating and Income Inequality," American Economic Review, 104, 348-53.

Hout, M. (1982): 'The Association between Husbands' and Wives' Occupations in Two-Earner Families," American Journal of Sociology, 88, 397-409.

International Labour Office (ILO) (2012): "International Standard Classification of Occupations 2008 (ISCO-08): structure, group definitions and correspondence tables," .

Iversen, T. And D. Soskice (2001): "An Asset Theory of Social Policy Preferences," American Political Science Review, 95, 875-893.

Karabarbounis, L. (2011): "One Dollar, One Vote," The Economic Journal, 121, 621-651.

Karadja, M., J. Mollerstrom, And D. Seim (2017): "Richer (and Holier) Than Thou? The Effect of Relative Income Improvements on Demand for Redistribution," The Review of Economics and Statistics, 99, 201-212.

Kenworthy, L. And L. MCCall (2007): "Inequality, public opinion and redistribution," Socio-Economic Review, 6, 35-68.

Luttmer, E. F. P. And M. Singhal (2011): "Culture, Context, and the Taste for Redistribution," American Economic Journal: Economic Policy, 3, 157-79.

Meltzer, A. H. And S. F. Richard (1981): "A Rational Theory of the Size of Government," Journal of Political Economy, 89, 914-927. 
Milanovic, B. (2000): "The median-voter hypothesis, income inequality, and income redistribution: an empirical test with the required data," $E u$ ropean Journal of Political Economy, 16, 367 - 410.

Minnesota Population Center (2019): "Integrated Public Use Microdata Series, International: Version 7.2[dataset]," .

Norton, M. I. And D. Ariely (2011): "Building a Better America-One Wealth Quintile at a Time," Perspectives on Psychological Science, 6, 9-12, pMID: 26162108.

Norton, M. I., D. T. Neal, C. L. Govan, D. Ariely, and E. HolLAND (2014): "The Not-So-Common-Wealth of Australia: Evidence for a Cross-Cultural Desire for a More Equal Distribution of Wealth," Analyses of Social Issues and Public Policy, 14, 339-351.

OECD (2016): "Income inequality remains high in the face of weak recovery," Income inequality update, Centre for Opportunity and Equality, November.

OECD Data (2019a): "Income inequality (indicator), Regional Well-Being Dataset (Accessed on 12 December 2019)," .

(2019b): "Regional GDP (indicator), Regional Economy Dataset (Accessed on 12 December 2019)," .

OliverA, J. (2015): "Preferences for redistribution in Europe," IZA Journal of European Labor Studies, 4, 14.

Ravallion, M. AND M. Lokshin (2000): "Who wants to redistribute?: The tunnel effect in 1990s Russia," Journal of Public Economics, 76, 87 104.

Rehm, P. (2011): "Social policy by popular demand," World Politics, 63, 271-299. 
SCERvini, F. (2012): "Empirics of the median voter: democracy, redistribution and the role of the middle class," The Journal of Economic Inequality, $10,529-550$.

Schwartz, C. R. (2013): "Trends and Variation in Assortative Mating: Causes and Consequences," Annual Review of Sociology, 39, 451-470.

Senik, C., H. Stichnoth, And K. Van der Straeten (2009): "Immigration and natives' attitudes towards the welfare state: evidence from the European Social Survey," Social indicators research, 91, 345-370.

Skopek, J., F. Schulz, And H.-P. Blossfeld (2010): "Who Contacts Whom? Educational Homophily in Online Mate Selection," European Sociological Review, 27, 180-195.

Smits, J., W. Ultee, And J. Lammers (1998): "Educational Homogamy in 65 Countries: An Explanation of Differences in Openness Using Country-Level Explanatory Variables," American Sociological Review, 63, 264-285.

Stevens, G. (1991): "Propinquity and educational homogamy," in Sociological Forum, Springer, vol. 6, 715-726.

Windsteiger, L. (2017): "The Redistributive Consequences of Segregation," Working Papers 2017-12, Max Planck Institute for Tax Law and Public Finance. 